\title{
Short Communication: Phenotypic diversity of male pelung chickens in West Java Province, Indonesia
}

\author{
INDRAWATI Y. ASMARA ${ }^{1}$, DANI GARNIDA ${ }^{1}$, IWAN SETIAWAN ${ }^{1}$, RUHYAT PARTASASMITA ${ }^{2, \boldsymbol{v}}$ \\ ${ }^{1}$ Faculty of Animal Husbandry, Universitas Padjadjaran. Jl. Raya Bandung-Sumedang Km 21, Jatinangor, Sumedang 45363, West Java, Indonesia \\ ${ }^{2}$ Department of Biology, Mathematics and Natural Science Faculty, Universitas Padjadjaran. Jl. Raya Bandung Sumedang Km. 21, Jatinangor, \\ Sumedang 45363, West Java, Indonesia. Tel.: +62-22-7796412 line. 104, Fax.: +62-22-7794545, `email: rp2010rikkyo@ gmail.com; \\ ruhyat.partasasmita@unpad.ac.id
}

Manuscript received: 27 May 2019. Revision accepted: 22 July 2019.

\begin{abstract}
Asmara IY, Garnida D, Setiawan I, Partasasmita R. 2019. Short Communication: Phenotypic diversity of male pelung chickens in West Java Province, Indonesia. Biodiversitas 20: 2243-2248. Pelung chickens are indigenous chickens from Cianjur District, West Java Province, Indonesia. The male chickens have long and beautiful crowing and have a distinct body figure compared to other indigenous chickens. Chicken contests are conducted regularly as media to show singing ability and body performance of Pelung chickens. Pelung chickens raised in different areas may have different phenotypic characteristics due to keeper preferences. Also, the phenotypic characteristics of the winners of chicken contests may influence keepers to select their chickens. The objective of this study was to determine the phenotypic characteristics of male Pelung Chickens in different areas in West Java, Indonesia. Comb type, as well as the color of eye, beak, skin, plumage, and shank, were recorded in the study. Data were collected through a survey involving 160 male birds in four different districts in West Java Province including Cianjur, Sukabumi, Bandung and Garut Districts. Key informant interview was carried out to support quantitative data. The results showed a limited variation of phenotypic characteristics among male Pelung chickens. Comb type, as well as skin and plumage colors, are criteria to select male Pelung chickens. Phenotypic characteristics of contest winners are also a reference for Pelung keepers in breeding selection.
\end{abstract}

Keywords: Animal genetic resources, conservation, indigenous chickens

\section{INTRODUCTION}

As one of the major chicken domestication centers in the world besides China and India (Sulandari et al. 2008), Indonesia has more than 30 different groups of chickens (Nataamijaya 2000). Chicken diversity may be caused by genotype difference due to demographic migration (Sartika et al. 2004) and farmer preferences to develop chickens for a specific use such as for socio-cultural function and entertainment (Komiyama et al. 2016; Bortoluzzi et al. 2018). Some of the chickens in Indonesia have been developed for social-cultural use, for example, Cemani chickens from Temanggung District, in Central Java Province, and Pelung chickens from Cianjur District, in West Java Province (Sulandari et al. 2007).

People in Cianjur raise Pelung chickens as singing roosters because the chickens have beautiful, long and rhythmically crowing. It was reported by Nataamijaya (2005) that a good male Pelung could reach 11 seconds in crowing. In terms of body conformation, Pelung chickens are tall and sturdy. Body weight of the chickens can obtain $5,400 \mathrm{~g}$ for male adult chickens, whereas 4,500 $\mathrm{g}$ for female adult chickens (Sulandari et al. 2007). The chickens do not have unique plumage colors or patterns; however, red, black and green are common colors found in plumage of male chickens, whereas black in females (Sulandari et al. 2007).
Nowadays, Pelung chicken can be found not only in Cianjur but also in other districts in West Java Province and other provinces in Indonesia. The wide distribution of Pelung chickens may be affected by singing contests for this chicken which make more people outside Cianjur interested to raise the chickens (Asmara 2014). In the contests, chickens compete to win singing and performance categories. In the singing category, chickens which have a longer crowing duration and have distinctive sound characteristics would be rated higher by contest juries. On the other hand, chickens with a minimum body weight of 5 $\mathrm{kg}$ and have color consistency from upper part until underpart of the body would have a higher probability to win performance category.

Currently, the winner of the chicken contest is not only dominated by chickens from Cianjur District but also from other areas such as Bandung and Garut Districts. The farmer from different areas may have different preferences for phenotypic characteristics such as plumage colors. Also, phenotypic characteristics of the winners of chicken contests may influence farmers to select male birds. Asmara (2018) stated that Pelung keepers perceived chicken contests as media to find good breeds. Trait preferences of farmers for local chickens are reported among others by Dana et al. (2010) and Markos et al. (2016). Study on phenotypic traits of Pelung chickens from one area has been conducted by Nataamijaya (2005). 
Unlike the previous study, the current study was conducted to determine the phenotypic characteristics of male Pelung chickens in Cianjur and three other districts in West Java, where Pelung chickens are spread. The findings would be essential as inputs for conservation design of this breed.

\section{MATERIALS AND METHODS}

\section{Description of research area}

The research areas were Garut, Bandung, Cianjur, and Sukabumi Districts in West Java Province, Indonesia (Figure 1). In general, Garut District is located at an altitude of $100-1500 \mathrm{~m}$. Mean annual rainfall in this area is $2,589 \mathrm{~mm}$ and annual temperature $24-27^{\circ} \mathrm{C}$ (Communication and Informatics Office of Garut District 2017). Bandung District is a highland area adjacent with Garut District. The annual rainfall in Bandung is 1,500$4,000 \mathrm{~mm}$ with an annual temperature between $12-24^{\circ} \mathrm{C}$ (Local Government of Bandung District 2017). Other study areas, Cianjur and Sukabumi Districts, are adjacent and located in southwestern of Java Island. Cianjur District is situated at an altitude of 7-2,962 m. This district has mean annual rainfall of 2,610 $\mathrm{mm}$ and mean annual temperature $24.4{ }^{\circ} \mathrm{C}$ (Communication, Informatics, Encoding and Statistics Office of Cianjur District 2017). Sukabumi District is situated at an altitude of 0-2,960 m. Sukabumi has an annual rainfall of 2,000-4,000 $\mathrm{mm}$ and annual temperature $18-30^{\circ} \mathrm{C}$ (Local Government of Sukabumi District 2016).

\section{Procedure}

A survey was conducted to collect data. A total of 160 male birds aged more than six months was involved in the study. Purposive sampling technique was chosen in the survey due to no precise information about the number of adult male Pelung chickens. Phenotypic characteristics including comb type, the color of eye, beak, skin, plumage, as well as shank are documented in the study. Distribution of trait frequency among chickens was determined by dividing the number of chickens with specific traits by the total number of birds investigated. The percentage was used to quantify the frequency of traits in study areas. In the study, data analysis used the Statistical Package for the Social Sciences (SPSS) IBM SPSS statistics 19. Key informant interviews were conducted to support the quantitative data derived from the study.

\section{RESULTS AND DISCUSSION}

\section{Results}

Table 1 shows the phenotypic characteristics of male Pelung chickens, excluding plumage color. The chickens found in the study had red single combs and red wattles with white skins. It was found different types of single combs named using traditional terms (Figure 2) such as Bajing Turun/luncat (climbing down/up squirrels' tailtyped comb), and Ngaplek (left/right-pendulous comb). Chickens with normal black beaks (sasiung bawang) and red eyes were found predominantly in the study (Figure 3). Higher diversity was identified in terms of shank colors.

In terms of plumage color, red and black were normally colors found in male Pelung chickens (Table 2). In particular, red plumage color was identified in some body parts including neck, back and wing. Black was predominant for chest and abdomen as well as tail plumage (Figure 4). Regarding plumage color, Garut had lower diversity compared to other areas.

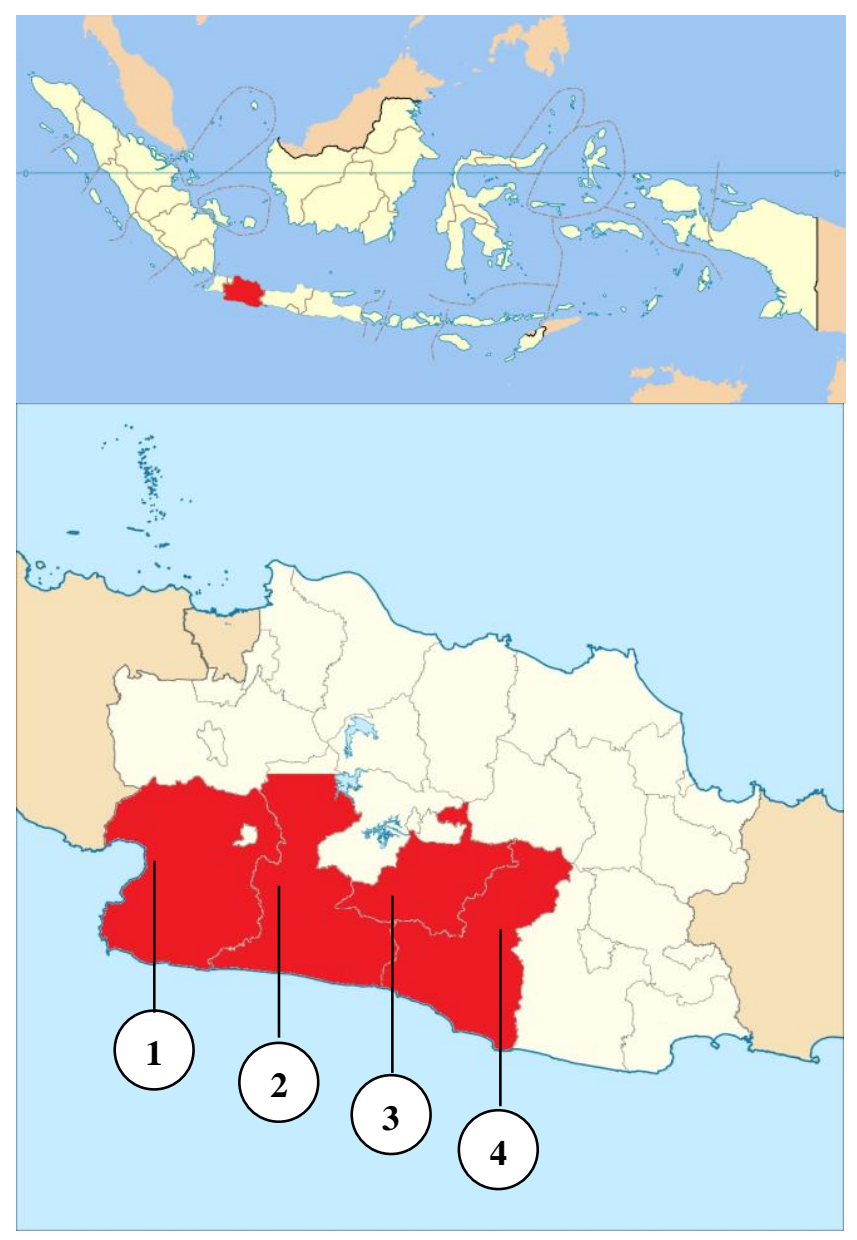

Figure 1. Research areas in West Java Province, Indonesia. 1. Sukabumi, 2. Cianjur, 3. Bandung, 4. Garut 


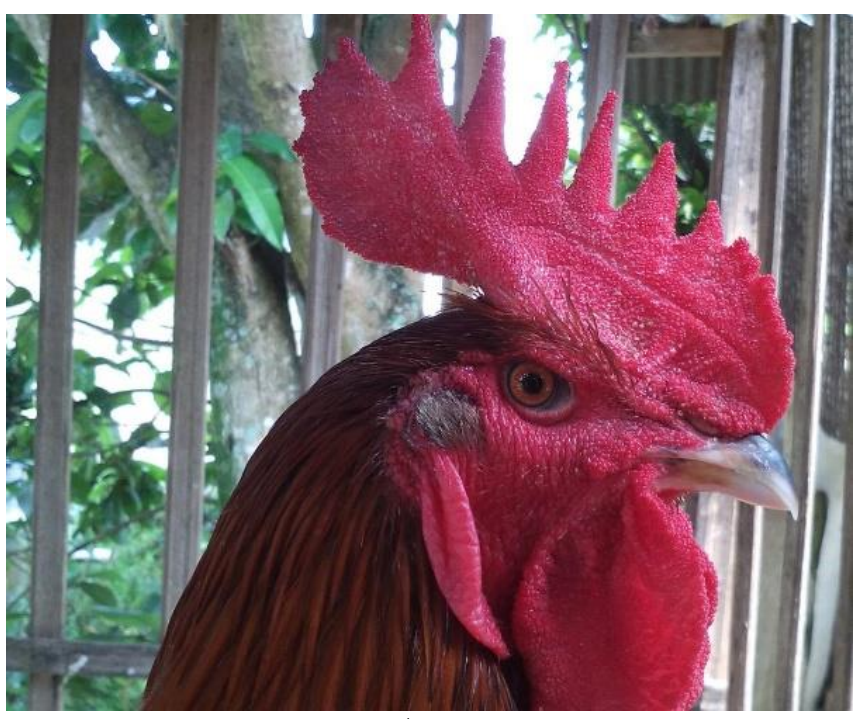

A

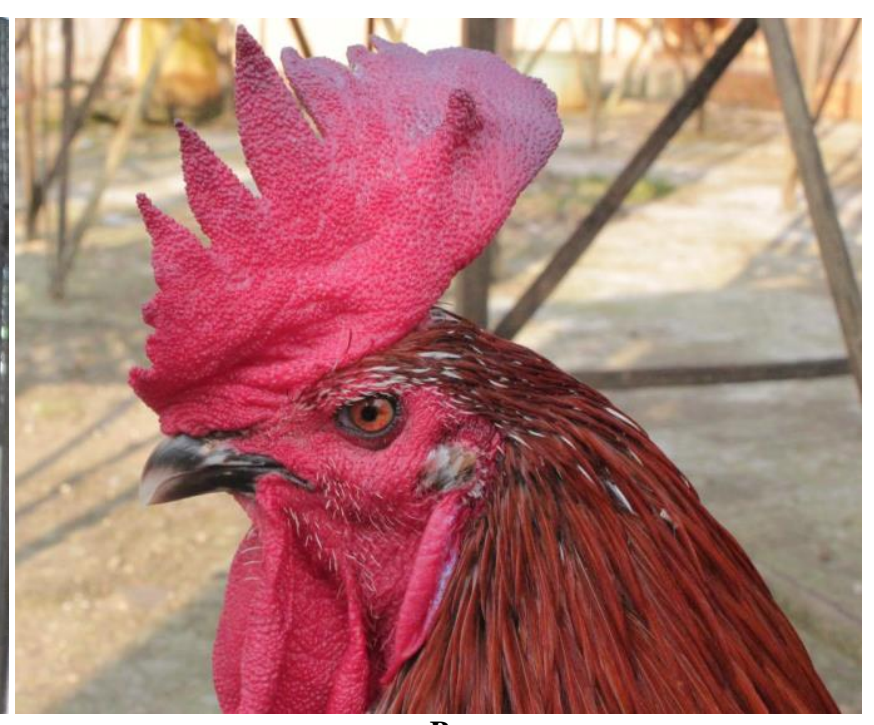

B

Figure 2. Images of single comb characteristics using traditional terms, A.Bajing Luncat Comb (Climbing up squirrels' tail-typed comb), B. Ngaplek Kanan Comb (Right-pendulous comb)

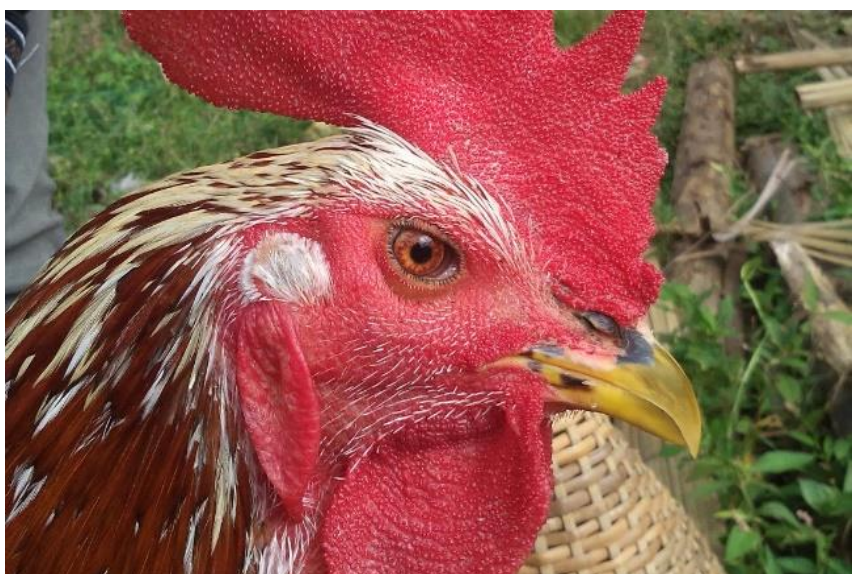

A

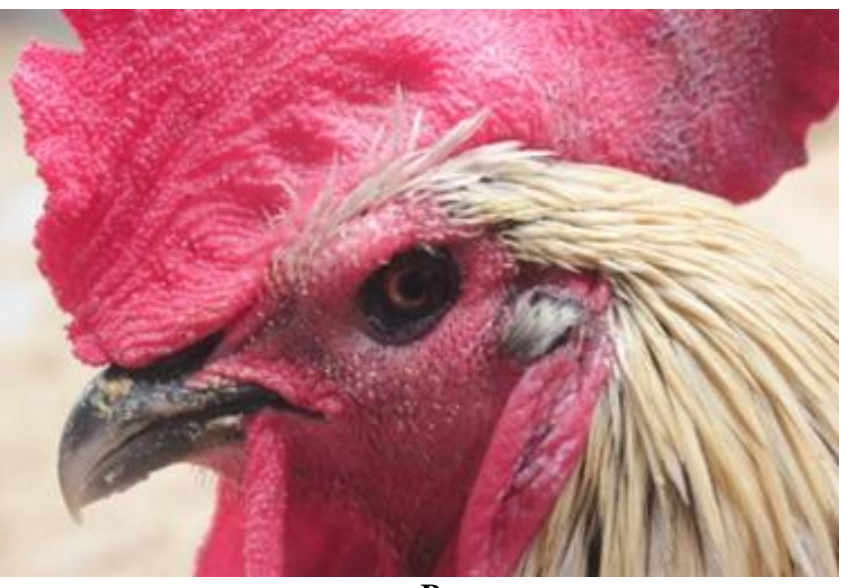

B

Figure 3. Images of eye, beak color and beak type of male Pelung chickens. A. Chickens with yellow eye and yellow normal beak, B. Chickens with black eye and black hooked beak

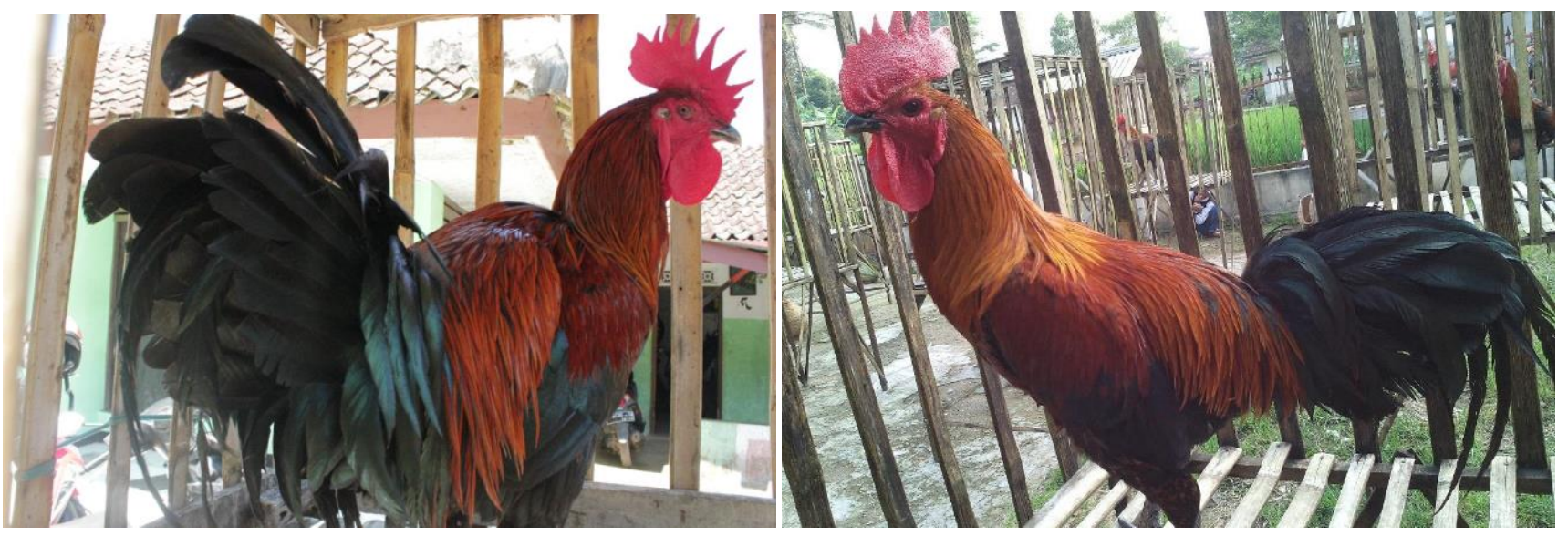

Figure 4. Dominant plumage color of male Pelung chickens 
Table 1. Phenotypic characteristics of male Pelung chickens

\begin{tabular}{|c|c|c|c|c|c|c|}
\hline \multirow{3}{*}{ Morphology } & \multirow{3}{*}{ Trait } & \multicolumn{4}{|c|}{ District } & \multirow[b]{2}{*}{ 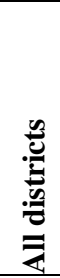 } \\
\hline & & 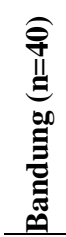 & 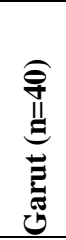 & & 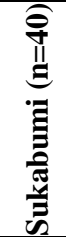 & \\
\hline & & \multicolumn{5}{|c|}{$(\%)$} \\
\hline Comb type & Single & 100 & 100 & 100 & 100 & 100 \\
\hline Comb & Bajing turun & 32 & 42 & 38 & 48 & 40 \\
\hline characteristic & Bajing luncat & 13 & 8 & 10 & 5 & 9 \\
\hline \multirow[t]{5}{*}{ (traditional name) } & Ngaplek kanan & 25 & 15 & 15 & 10 & 16 \\
\hline & Ngaplek kiri & 5 & 22 & 7 & 5 & 10 \\
\hline & Gelung bandung & 7 & 5 & 7 & 12 & 8 \\
\hline & Ngabendo & 3 & 3 & 15 & 10 & 8 \\
\hline & Ngabaret & 15 & 5 & 8 & 10 & 9 \\
\hline \multirow[t]{2}{*}{ Comb color } & Red & 100 & 100 & 100 & 100 & 100 \\
\hline & Dark red & 0 & 0 & 0 & 0 & 0 \\
\hline \multirow[t]{2}{*}{ Wattle color } & Red & 100 & 100 & 100 & 100 & 100 \\
\hline & Dark red & 0 & 0 & 0 & 0 & 0 \\
\hline \multirow[t]{3}{*}{ Beak color } & Yellow & 17 & 15 & 13 & 10 & 14 \\
\hline & White & 13 & 20 & 32 & 25 & 22 \\
\hline & Black & 70 & 65 & 55 & 65 & 64 \\
\hline Beak shape & $\begin{array}{l}\text { Normal beak } \\
\text { (Sasiung bawang) }\end{array}$ & 73 & 70 & 75 & 80 & 74 \\
\hline (Traditional name) & $\begin{array}{l}\text { Hooked beak } \\
\text { (Pamatuk ekek) }\end{array}$ & 27 & 30 & 25 & 20 & 26 \\
\hline \multirow[t]{3}{*}{ Eye color } & Yellow & 17 & 15 & 7 & 20 & 15 \\
\hline & Red & 70 & 70 & 70 & 55 & 66 \\
\hline & Black & 13 & 15 & 23 & 25 & 19 \\
\hline \multirow[t]{2}{*}{ Skin color } & White & 100 & 100 & 100 & 100 & 100 \\
\hline & Black & 0 & 0 & 0 & 0 & 0 \\
\hline \multirow[t]{4}{*}{ Shank color } & Black & 42 & 37 & 32 & 53 & 41 \\
\hline & White & 35 & 30 & 40 & 17 & 31 \\
\hline & Yellow & 8 & 8 & 20 & 20 & 14 \\
\hline & Grey & 15 & 25 & 8 & 10 & 14 \\
\hline
\end{tabular}

\section{Discussion}

In general, domestic fowls have four types of combs; single, pea, rose, and walnut (Stevens 1991). The current study indicated that male Pelung chickens from all study areas have single combs. This type of comb is frequently found in other tropical countries such as Sri Lanka as reported by Liyanage et al. (2015). Also, it was reported that the majority of indigenous chickens in Africa have single combs (Duguma 2006; Apuno et al. 2011; Rotimi et al. 2016). Single comb could be advantageous for chickens in hot regions for releasing heat in high-temperature condition (Duguma 2006).

The current study reveals that comb is a criterion for selection of breeding stocks Organization for Pelung keepers and hobbyist, Himpunan Peternak dan Penggemar Ayam Pelung Indonesia or HIPPAPI (2012) stated that Pelung keepers believe that single comb is a purity indicator for Pelung chickens. The keepers are certain that the ancestor of Pelung chickens is the Red Jungle Fowl (Gallus gallus) which can be distinguished by their single combs. In addition, Pelung keepers believe that a winning
Table 2. Plumage color of Pelung chickens

\begin{tabular}{|c|c|c|c|c|c|c|}
\hline \multirow{3}{*}{ Body part } & \multirow{3}{*}{ Color } & \multicolumn{4}{|c|}{ District } & \multirow[b]{2}{*}{ 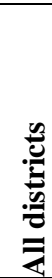 } \\
\hline & & 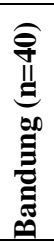 & 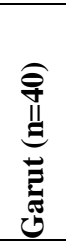 & 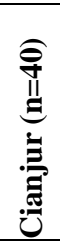 & 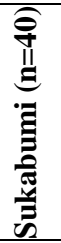 & \\
\hline & & \multicolumn{5}{|c|}{$(\%)$} \\
\hline \multirow[t]{5}{*}{ Neck } & Red black & 40 & 8 & 25 & 28 & 25 \\
\hline & Red & 38 & 80 & 50 & 47 & 54 \\
\hline & Red yellow & 12 & 2 & 13 & 13 & 10 \\
\hline & White & 5 & 0 & 7 & 5 & 4 \\
\hline & Yellow & 5 & 10 & 5 & 7 & 7 \\
\hline \multirow[t]{5}{*}{ Back } & Red & 30 & 35 & 15 & 20 & 25 \\
\hline & Red black & 50 & 43 & 50 & 45 & 47 \\
\hline & Yellow black & 8 & 10 & 15 & 18 & 13 \\
\hline & White & 5 & 7 & 13 & 7 & 8 \\
\hline & Yellow & 7 & 5 & 7 & 10 & 7 \\
\hline \multirow[t]{7}{*}{ Wing } & Red & 0 & 0 & 18 & 20 & 9 \\
\hline & Dark brown & 13 & 10 & 0 & 0 & 6 \\
\hline & Red black & 45 & 65 & 40 & 40 & 48 \\
\hline & Golden yellow & 0 & 0 & 10 & 8 & 4 \\
\hline & Yellow black & 2 & 8 & 13 & 10 & 8 \\
\hline & White & 2 & 2 & 7 & 12 & 6 \\
\hline & Yellow & 38 & 15 & 12 & 10 & 19 \\
\hline \multirow{4}{*}{$\begin{array}{l}\text { Chest and } \\
\text { Abdomen }\end{array}$} & Black & 53 & 80 & 55 & 53 & 60 \\
\hline & Yellow & 0 & 0 & 13 & 20 & 8 \\
\hline & White & 12 & 13 & 17 & 12 & 14 \\
\hline & White black & 35 & 7 & 15 & 15 & 18 \\
\hline \multirow[t]{2}{*}{ Tail } & Black & 88 & 83 & 75 & 80 & 81 \\
\hline & White black & 12 & 17 & 25 & 20 & 19 \\
\hline
\end{tabular}

contest rooster frequently has single comb (HIPPAPI 2012).

HIPPAPI (2000) categorize single comb into five characters using local terms. The local terms for single comb categorization which is only applied for Pelung chickens consisted of bajing turun, bajing luncat, gobed nyarande, ngabaret, and ngaplek. The current study indicated that Bajing turun (climbing down squirrels' tailtyped comb) is commonly found in all study areas. A similar finding was stated by Asmara et al. (2019) for female Pelung chickens. The local term for chicken traits was also reported by among others, Dana et al. (2010) who studies indigenous chickens in Ethiopia. Documentation of local terms used by keepers of Pelung chickens is required as input for the conservation of the chickens in the future.

This study revealed that red is the predominant color for eyes of male Pelung chickens, while yellow and black are minor. The three eye colors were also stated by Brown et al. (2017), who characterized local chickens in Ghana. Two types of melanin, eumelanin (responsible for brown/black color) and pheomelanin (responsible for yellow/red color), synthesize the eye pigmentation (Steven 1991). For 
domestic species, eye color is subject to change due to age and carotenoid from diets (Negro et al. 2017) as well as genes (Corti and Vogelaar, 2010; Gwaza et al. 2018). Eye color variation may be due to age differences among chickens. At hatched, all chicks except for albinos have dark eyes, and they have definitive eye color after sexual maturity (Corti and Vogelaar, 2010). In several wild birds, color transitions of eyes start from dark to lighter colors, for example from yellow to red (Negro et al. 2017).

In terms of diets, iris, the colored part of chicken' eye, is able to store carotenoids from diets (Corti and Vogelaar 2010). Common carotenoid sources are plants which give the yellow-orange-red color (Mortensen 2006). It was common for Pelung keepers to add vegetables in diets of Pelung chickens (Nataamijaya 2005; Iskandar and Susanti 2007; Asmara 2014). The yellow and red-eye colors may be caused by carotenoid pigments, while a black eye caused by Fibro melanotic gene (extended black, E). The gene is characterized by heavy eumelanin deposits throughout the eye (Corti and Vogelaar 2010; Gwaza et al. 2018). In addition, red-eye color may have resulted from the existent of capillaries in which the blood is flowing in iris. The red color of iris in male chickens is more intense than that in female chickens as red blood cells in male chickens are greater than in female (Corti and Vogelaar 2010). Red eyes were more frequent in cocks than in hens of local chickens in Ghana (Brown et al. 2017).

The existence of melanin is important in chicken pigmentation not only for eyes but also for beak, shank and skin (Jorge and Cunha 2008). The main color of the beak in the current study was black which might be due to high melanin concentration. This finding is in correspond with a study by Nataamijaya (2005) who reported that all male Pelung chickens in Garut District had black beaks. However, Nataamijaya (2005) did not document beak shape in this area. Pelung keepers believe that rooster with normal beak (sasiung bawang) will have good crowing quality; hence they prefer to have sasiung bawang chickens. The current study showed that the main beak shape in study areas was sasiung bawang, whereas pamatuk ekek (hooked beak) was a subsidiary. Diseases, environmental factor, and nutrition, as well as genetic effect, contribute to beak deformity (Bai et al. 2014).

Varied shank color (black, white, yellow, and grey) were documented in the current study. The previous study conducted by Nataamijaya 2005 as well as Iskandar and Susanti 2007 revealed similar findings. The shank color is a result of interaction between the melanin and carotenoids deposited in the dermis and epidermis (Xu et al. 2017). In Pelung contest, color consistency between beak and shank is important in performance category (HIPPAPI 2012). Nowadays, the contest winner in performance category dominated by chickens which have black beak and shank. As a consequence, the keepers prefer to have blacked beak and shank chickens.

The current study showed that Pelung chickens have white skin. In a study reported by Nataamijaya (2005), a small number of blacked skin chickens were documented. White-skinned chickens were preferable since the traits reflect the Red Jungle Fowl characteristics that are believed by Pelung keepers as the ancestor of Pelung chickens. Similar to shank color, the existence of melanin pigments in dermis and epidermis influences skin color in chickens (Duguma 2006). It was common that chickens with black shanks and beaks have white skins. Based on phylogenetic analysis using the beta-carotene dioxygenase 2 (BCDO2) gene, Gao et al. (2017) stated that this type of chickens might be originated from the Red Jungle Fowl. The Red Jungle Fowl (G. gallus) is believed to be the wild ancestor of the domestic chicken (Tixier-Boichard et al. 2011).

In terms of plumage color, the study revealed that red and black were the primary color for male Pelung chickens in particular in Garut District. This finding is similar to another study for Pelung chickens in Garut District conducted by Nataamijaya (2005). According to Decree No. 2918/2011 issued by Minister of Agriculture Republic of Indonesia, plumage color of male Pelung chickens is varied and do not have a unique pattern. The plumage of male Pelung chickens has a combination of red, black, yellow and white as well as shiny green. Pelung keepers believe that a pure male Pelung chickens have red and black plumage characteristics like their ancestor, the Red Jungle Fowl. Currently, the keepers shifting their preferences by choosing blacked plumage roosters since this type of chickens are commonly winning the chicken contest in the performance category.

Several different loci are responsible for plumage expressions. Among them, the Extension (E) locus is the main loci controlling the distribution of black (eumelanin) and red (phaeomelanin) pigment (Kerje et al. 2003). ER, e+, eb, and ewh have been identified as locus alleles in chickens (Ellet 2000). The Red Jungle Fowl possess the e+ gene (wild-type), and the gene expresses the black-red color (Stevens 1991). Hence; findings in the current study support the belief of the keepers in all study areas who are certain that the ancestor of Pelung chickens is the Red Jungle Fowl.

The study reveals a limited variation of phenotypic characteristics among male Pelung chickens in different areas in West Java. Some phenotypic traits, including comb-type as well as skin and plumage colors, are criteria to select good Pelung chickens. Also, the current study shows that phenotypic characteristics of the winners of Pelung contests might influence Pelung keepers in breeding selection. The study provides important information for Pelung conservation scheme.

\section{ACKNOWLEDGEMENTS}

We would like to express our special thanks of gratitude to Rector of Universitas Padjadjaran (Unpad), Bandung, Indonesia, for funding this study through Hibah Internal Unpad (HIU) grant. We would also like to acknowledge with much appreciation to Saiful, who assisted us in data collection and provided us with pictures of Pelung chickens. 


\section{REFERENCES}

Apuno AA, Mbap ST, Ibrahim T. 2011. Characterization of local chickens (Gallus gallus domesticus) in shelleng and song local government areas of Adamawa State, Nigeria. Agric Biol J North Am 2 (1): 6-14

Asmara IY. 2014. 'Risk Status of Selected Indigenous Chicken Breeds in Java, Indonesia: Challenges and Opportunities for Conservation', [Dissertation]. Research Institute for the Environment and Livelihoods, Faculty of Engineering, Health, Science and the Environment, Charles Darwin University, Darwin, NT, Australia

Asmara IY, Garnida D, Sulistyati M, Tejaningsih S, Partasasmita R. 2018 Knowledge and perception of pelung keepers's toward chicken contests in West Java, Indonesia. Biodiversitas 19 (6): 2232-2237

Asmara IY, Garnida D, Tanwiriah W. Partasasmita R. 2019. Qualitative morphological diversity of female Pelung Chickens in West Java, Indonesia. Biodiversitas 20 (1): 126-133.

Bai H, Zhu J, Sun Y, Liu R, Liu N, Li D, Wen J, Chen J. 2014.Identification of Genes Related to Beak Deformity of Chickens Using Digital Gene Expression Profiling. PLoS ONE 9 (9): e107050 DOI: 10.1371/journal.pone.0107050.

Bortoluzzi C, Crooijmans RPMA, Bosse M, Hiemstra SJ, Groenen MAM, Jan Megens H. 2018. The effects of recent changes in breeding preferences on maintaining traditional Dutch chicken genomic diversity. Heredity 121 (6): 564-578

Brown MM, Alenyorege B, Teye GA, Roessler R. 2017. Phenotypic diversity, major genes and production potential of local chickens and guinea fowl in Tamale, northern Ghana. Asian-Austral J Anim Sci 30: 1372-1381.

Corti E, Vogelaar E. 2010. Concerning poultry: the eye, Avia-culture Europe. http: //www.aviculture-europe.nl/nummers/10E06A11.pdf

Dana N, van der Waaij LH, Dessie T, van Arendonk JAM. 2010 Production objectives and trait preferences of village poultry producers of Ethiopia: implications for designing breeding schemes utilizing indigenous chicken genetic resources. Trop Anim Health Product 42: 1519-1529

Duguma R. 2006. Phenotypic characterization of some indigenous chicken ecotypes of Ethiopia. Livestock Res Rural Dev 18 (9) http: //www.lrrd.org/lrrd18/9/cont1809.htm

Ellett A. 2000. Melanocortin-1-Receptor (MCR-1) gene polymorphisms associated with the chicken $E$ locus alleles. Inquiry: The University of Arkansas Undergraduate. Res J 1: 1-5

Gao YS, Jia X, Tang X, Fan Y, Lu J, Huang S, Tang M. 2017. The genetic diversity of chicken breeds from Jiangxi, assessed with BCDO2 and the complete mitochondrial DNA D-loop region. PLoS ONE 12 (3): e0173192. DOI: 10.1371/journal.pone.0173192.

Gwaza DS, Dim NI, Momoh OM. 2018. Inheritance of qualitative traits in two populations of Nigerian local chicken ecotypes. J Res Rep Genet 2 (2): 22-28.

HIPPAPI. 2000. Guidelines of standardization and development of pelung chickens (Gallus domesticus var pelung). HIPPAPI of Cianjur, Cianjur, West Java, Indonesia. [Indonesian]

HIPPAPI. 2012. Regeneration and training for juries of pelung chickens. HIPPAPI of Cianjur, Cianjur, West Java, Indonesia. [Indonesian]
Iskandar S, Susanti T. 2007. Characteristics and use of pelung chickens in Indonesia. Wartazoa 17 (3): 128-136. [Indonesian]

Jorge W, Cunha LM. 2008. Inheritance of a new albino mutation in Brazilian free-range black chickens. Brazilian J Poultry Sci 10 (3): 153-156.

Kerje S, Lind J, Schutz K. Jensen P, Andersson L. 2003. Melanocortin 1 receptor (MC1R) mutations are associated with plumage colour in chicken. Anim Gen 34: 241-248.

Komiyama T, Lin M. Ogura A. 2016. A CGH Analysis to Estimate Genetic Variations among Domesticated Chickens, BioMed Res Intl. DOI: $10.1155 / 2016 / 1794329$

Liyanage RP, Dematawewa CMB, Silva GLLP. 2015. Comparative study on morphological and morphometric features of village chicken in Sri Lanka. Trop Agri Res 26 (2): 261-273.

Markos S, Belay B, Dessie T. 2016. Village chicken breeding practices, objectives and farmers' trait preferences in western zone of Tigray, Northern Ethiopia. J Agri Res Develop 6 (1): 1-11

Mortensen A. 2006. Carotenoids and other pigments as natural colorants. Pure Appl Chem 78 (8): 1477-1491

Negro JJ, Blázquez MC, Galván I. 2017. Intraspecific eye color variability in birds and mammals: a recent evolutionary event exclusive to humans and domestic animals. Frontiers Zool 14 (53): 1-6

Nataamijaya AG. 2000. The native chicken of Indonesia. Bull Germ Plasm 6 (1): 1-6.

Nataamijaya AG. 2005. Phenotypic characteristics of plumage pattern, skin, shank and beak of pelung chickens in Garut and Sentul chickens in Ciamis. Bull Plasma Nutfah 11 (1): 1-6. [Indonesian]

Rotimi EA, Egahi JO, Adeoye AA. 2016. Phenotypic characterization of indigenous chicken population in Gwer-West, Benue State, Nigeria. World Sci News, 53 (3): 343-353.

Sartika T, Iskandar S, Prasetyo LH, Takahashi H, Mitsuru M. 2004. Genetic relationships of Kampung, Pelung, Sentul and Black Kedu chickens were studied on the basis of microsatellite DNA polymorphism: I. linkage group of macrochromosome. J Anim Veterinary Sci, 9 (2): 81-86. [Indonesian]

Stevens, L 1991. Genetics and evolution of the domestic fowl. Cambridge University Press, Australia

Sulandari S, Zein MSA, Paryanti S, Sartika T, Astuti M, Widjastuti T, Sujana E, Darana S, Setiawan I, Garnida D. 2007. Local chicken genetic resources, in Diwyanto K, Prijono SN. (eds), The biodiversity of Indonesia's local chicken resources: benefits and potential, LIPI Press, Jakarta, Indonesia. [Indonesian]

Sulandari S, Zein MSA, Sartika T. 2008. Molecular characterization of Indonesian indigenous chicken based on mitochondrial DNA displacement (D)-loop sequences. J Biosci 15 (4): 145-154

Tixier-Boichard M, Bed'homa B, Rognon X. 2011. Chicken domestication: From archeology to genomics. Comptes Rendus Biologies 334: 197-204.

Xu J, Lin S, Gao X, Nie Q, Luo Q, Zhang X. 2017. Mapping of Id locus for dermal shank melanin in a Chinese indigenous chicken breed. J Genetics 96 (6): 977-983. 